\title{
GROWTH AND YIELD OF CUCUMBER AS INFLUENCED BY POULTRY MANURE IN ASABA AREA OF DELTA STATE, NIGERIA
}

EC Enujeke

Department Of Agronomy, Delta State University, P.M.B 95074, Asaba Campus, Nigeria

Accepted: $25^{\text {th }}$ July 2014

\begin{abstract}
Field experiments were conducted in 2011 and 2012 cropping seasons in the Teaching and Research Farm of Delta State University, Asaba Campus, Nigeria to evaluate the growth and yield responses of cucumber to five different rates of poultry manure. The study was carried out in a Randomized Complete Block Design (RCBD) with three replicates. Rates of poultry manure in tons per hectare were $0,5,10,15$ and 20 , while the parameters investigated were vine length, number of leaves per plant, fruit diameter (cm), fruit length (cm), and fruit weight of 'Marketmore'variety of cucumber. The results of the study showed that parameters assessed were significantly influenced by the application of poultry manure. At 4, 6 and 8 weeks after planting, plants that received highest rate of poultry manure $\left(20\right.$ tha $\left.^{-1}\right)$ showed greatest performances. Based on the findings of the study, it was recommended that farmers in the study area can apply 20 tha $^{-1}$ of poultry manure to increase growth and yield of cucumber.
\end{abstract}

Key words: Growth and yield of Cucumber, Rates of poultry manure, Asaba, Nigeria

\section{INTRODUCTION}

Cucumber (Cucumis sativa L) is one of the monoecious annual crops. It belongs to the $\mathrm{Cu}$ curbitaceae family that has been cultivated by man for over 3, 000 years (Adetula and Denton, 2003; Okonmah, 2011). With respect to economic importance, it ranks fourth after tomatoes, cabbage and onion in Asia, and second after tomato in Western Europe (Eifediyi and Remison, 2010). However, due to limited use, its place has not been ranked in tropical Africa. Cucumber is a soft and succulentvegetable crop and is cherished by man, and eaten in salads or sliced into stew in tropical regions. It's juice is often recommended as source of silicon to improve the health and complexion of the skin (Duke, 1997). Cucumber is a very good source of such vitamins as $\mathrm{A}, \mathrm{C}, \mathrm{K}, \mathrm{B}_{6}$, pantothenic acid, and minerals such as potassium, magnesium, phosphorus, copper and manganese (Vimala et al., 1999). The ascorbic acid and caffeic acid contained in cucumber help to reduce skin irritation and swollen (Okonmah, 2011).

\footnotetext{
*Corresponding author: enujeke@yahoo.com
}

In spite of the increasing relevance of cucumber in Nigeria, low yields are obtained in farmers' fields because of declining soil fertility due to continuous cropping and disregard for soil amendment materials. Application of poultry manure is one of the ways of improving soil fertility and final yield of crops. Reported as the richest known animal manure, Lombin et al., (1991); Mangila et al., (2007) and Enujeke et al., 2013 indicated that poultry manure is not only cheap and effective but is also essential for establishing and maintaining the optimum soil physical conditions for plant growth and yield. As a good source of $\mathrm{N}$ for sustainable crop production, Ewulo et al., (2008) and Agbede et al., (2008)reproted that the application of $10-50$ tha $^{-1}$ of poultry manure improves the soil physical properties by reducing soil temperature and bulk density, and increasing the total porosity. Adekiya and Ojeniyi (2002) and Ewulo et al., (2008) reported that high rates of poultry manure improves moisture availability which results in improved nutrient release to plants for increased growth and yield. According to Agbede et al.,( 2008), poultry manure increased plant $\mathrm{N}, \mathrm{P}, \mathrm{K}, \mathrm{Ca}$ and $\mathrm{Mg}$ status in 
leaf of Sorghum. He also reported that the application of poultry manure increased plant height, leaf area, stem diameter, number of roots, shoot weight and grain weight in the years of evaluation. Enujeke (2013) reported that 20 tha $^{-1}$ of poultry manure significantly increased the vine length, number of leaves/ plant, number of branches/plant, and fruit weight of watermelon above their control counterparts. John et al., (2004)and Dauda et al., (2008) attributed the vigorous growth and increased fruit yield of watermelon to increased supply of nutrient elements associated with high photosynthetic activities which promote growth and yield. Aliyu, (2000) made similar report that higher rates of poultry manure resulted in higher yield of eggplant. The nutrient composition of poultry manure as reported by DIPA (2006) is $1.0-1.8 \% \mathrm{~N}, 0.4-0.8 \% \mathrm{P}$, and $0.5-1.9 \% \mathrm{~K}$. This high level of nutrients contained in it, therefore, makes it a suitable soil amendment material for increased growth and yield of crops.

In the study area, there are no recommended standards with respect to the most appropriate rate of application of poultry manure for increased growth and yield of cucumber at present. The objective of this study, therefore, was to identify the most appropriate rate of application of poultry manure for enhanced growth and yield of cucumber in Asaba area of Delta State, Nigeria.

\section{MATERIALS AND METHODS}

\section{Description of experimental site, field and laboratory studies}

Field experiments were carried out at the Research and Teaching Farms of Anwai Campus of the Delta State University. The study site is located within latitude $06^{\circ} 14^{\prime} \mathrm{N}$ and longitude $06^{\circ} 49^{\prime} \mathrm{E}$ of the equator. The study was conducted during the 2011/2012 cropping seasons in a typical humid environment that is characterized by a bimodal rainfall pattern with peaks in July and September and an interrupted dry spell in August. The mean annual rainfall is about $1,650 \mathrm{~mm}$, the mean annual temperature is $37.3^{\circ} \mathrm{C}$ and the mean relative humidity is 73.2\% (NIMET, 2011). By nature of its geomorphological settings, the study area falls within the classification of Ancient metamorphiccrystalline basement complex formation which are more acid than base (Egbuchua, 2007). They are essentially gneisses and pegmatites that gave rise to coarse-textured soils that are deficient in dark ferromagnessium minerals (Egbuchua, 2007). The topography is undulating with pockets of hills, and land use is typically based on rain - fed agriculture with root, tuber, spices, pulses and vegetables prominently cultivated. The vegetation is of rainforest origin but has been drastically reduced to derived savanna due to continuous use of the land.

A land measuring $323.2 \mathrm{~m}^{2}(32.0 \mathrm{~m} \times 10.1 \mathrm{~m})$ was selected for the study and prepared by using a tractor to plough and harrow the land. It was marked out according to the experimental layout. Fifteen plots of $6.0 \mathrm{~m} \times 2.7 \mathrm{~m}$ each were made and composite samples collected from the plots at $0,-15 \mathrm{~cm}$ depth in order to assess the initial physio-chemical properties of the soil.

After 2 weeks of incorporation of manure, the composite soil samples collected from the individual plots were air-dried in a room temperature of $27^{\circ} \mathrm{C}$ for three days, crushed and sieved using $2 \mathrm{~mm}$ aperture. The parameters evaluated include the particle size distribution by hydrometer method (Gee and Bauder, 1986). The $\mathrm{pH}$ was determined using Pye Unican model MK2 pH meter in a 1:2:5 soil/water suspension ratio. Organic carbon was determined by Walkley-Black wet oxidation method (Nelson and Sommers, 1982). Total nitrogen was determined by micro-Kjeldahl distillation technique as described by Bremmer and Mulvaney (1982). Available phosphorus was determined by Bray No. 1 method (IITA, 1979). Exchangeable potassium was determined by flame photometer, while cation exchange capacity (CEC) was determined by Amnonium acetate saturation method (Roades, 1982). The chemical analysis of the poultry manure used 
for the experiment was also evaluated using appropriate methods as described in the IITA manuals (1979).

The experiment was carried out in a Randomized Complete Block Design (RCBD) with three replicates. Rates of poultry manure applied in tons per hectare were $0,5,10,15$ and 20 . The manure was incorporated into the soil 2 weeks before planting. Seeds of proven variety of cucumber (Market more) were obtained from Agro-Allied Company, Ibadan. They were sown on the plots at the rate of 3 seeds/stand at a spacing of $1 \mathrm{~m} \times 1 \mathrm{~m}$ and at a depth of $2.5 \mathrm{~cm}$, but the seedlings were later thinned to 1 seedling/stand, giving a plant population of 36 plants/plot. Alley pathways of $1 \mathrm{~m}$ were made for easy access to the plots. Regular weeding was done around the base, along and ahead of the vines using hoe. Fourteen middle stands were used as sample population. At forth - night intervals, vine length and number of leaves/plant commencing at 4 weeks after sowing, while fruit diameter $(\mathrm{cm})$, fruit length $(\mathrm{cm})$, and fruit weight were measured at maturity. Vine length was measured using tape from the base to the growing tip of the plant. Number of leaves/plant were determined by direct counting. Fruit diameter and fruit length were measured using tape rule, while fruit weight was measured using a weighing scale after harvest. Data collected was subjected to analysis of variance (ANOVA) and means were separated using Duncan Multiple Range Test (DMRT) according to Wahua (1999).

\section{RESULTS AND DISCUSSION}

\section{Initial soil properties}

The data on the initial physico-chemical properties of the soilof experimental area is presented in Table 1. The particle size fracture showed that the soils were sandy loam in texture and low in fertility as reflected by the low content of organic matter $\left(15.5 \mathrm{gkg}^{-1}\right)$, and total nitrogen $\left(0.87 \mathrm{gkg}^{-1}\right)$. Soil $\mathrm{pH}$ was strongly acid with a mean $\mathrm{pH}$ value of 5.3. The available phosphorus $(\mathrm{P})$ and water soluble, potassium $(\mathrm{K})$ values were $5.35 \mathrm{mgkg}^{-1}$ and $0.17 \mathrm{cmolkg}^{-1}$ and these values were lower than the ratings of FMANR, (1996) for the ecological zone. The low fertility status of the soils is a true reflection of most ultisols of humid environment that are strongly weathered of low activity clay mineralogy and high acidity due to intense precipitation with its associated erosion and leaching in the environment.

Table 1: Initial phyisco-chemical properties of the soils used for the study

\begin{tabular}{ll}
\hline $\begin{array}{l}\text { Parameters } \\
\text { Measured }\end{array}$ & Values obtained \\
\hline Particle size fractions & \\
Sand (\%) & 85.0 \\
Silt (\%) & 9.6 \\
Clay (\%) & 4.4 \\
Textural class & Sandyloam \\
pH $\left(\mathrm{H}_{2} \mathrm{O}\right)$ & 5.3 \\
Organic matter $\left(\mathrm{gkg}^{-1}\right)$ & 15.5 \\
Total Nitrogen $\left(\mathrm{gkg}^{-1}\right)$ & 0.87 \\
& 5.35 \\
Available $\mathrm{P}\left(\mathrm{mgkg}^{-1}\right)$ & 0.17 \\
Exchangeable K $\left(\mathrm{Cmolkg}^{-1}\right)$ & 10.13 \\
CEC $(\mathrm{Cmolkg}$ & \\
\hline
\end{tabular}

Effects of poultry manure on vine length (cm) of cucumber in 2011 and 2012

The response of vine length of cucumber to poultry manure in 2011 and 2012 cropping seasons is shown in Table 2. Vine length gradually increased from 4-8 weeks after planting. At 4 weeks after planting, plants that received 20 tha $^{-1}$ of poultry manure had the highest vine length with mean value for 2011 and 2012 as $116.2 \mathrm{~cm}$. Plants that did not receive manure had the lowest vine length with mean value of $46.1 \mathrm{~cm}$ for 2011 and 2012 . During the $6^{\text {th }}$ week after planting, plants that received 20 tha $^{-1}$ of poultry manure also had the highest vine length with mean value of $144.5 \mathrm{~cm}$ for both years of evaluation, while plants in the control plot had the lowest vine length with mean value of $80.5 \mathrm{~cm}$ for 2011 and 2012. The trend did not change during the 
$8^{\text {th }}$ week after planting. Plants that received 20 tha $^{-1}$ of poultry manure were superior in vine length over other plants, with mean value of $167.3 \mathrm{~cm}$. The superiority in vine length of cucumber based on rate of poultry manure received in tons/hectares was $20>15>10>5>0$.

Cucumber plants that received poultry manure application rate of 20 tha $^{-1}$ had longer vine length than other plants possibly because higher rate of manure improved moisture availability which enhanced the release of more nutrient elements for increased vine growth. This is consistent with the findings and reports of Adekiya and Ojeniyi (2002), and Ewuloet al., (2008) which attributed increased growth of crop plants to the release of more nutrient elements through the moisture that has been made available by the manure. It is also in harmony with the report of John et al., (2004) who indicated that poultry manure released essential elements which promoted high photosynthetic activities that enhanced growth and yield of watermelon. tha $^{-1}$ of manure were outstanding in number of leaves/plant with mean value of 14.6 at the $4^{\text {th }}$ week of 2011 and 2012, while plants in control plot had the lowest number of leaves/ plant with mean value of 6.3 . During the $6^{\text {th }}$ week after planting, plants that received 20 tha $^{-1}$ of manure also had the highest number of leaves/plant with mean value of 46.3 for 2011 and 2012. Plant grown without manure had the lowest number of leaves/plant with mean value of 30.1 for both years investigated. At $8^{\text {th }}$ weeks after planting, plants that received 20 tha $^{-1}$ of poultry manure were also superior to other plants with respect to number of leaves /plant (56.4). Plants grown without poultry manure had the lowest number of leaves/plants with mean value of 43.3 for 2011 and 2012. The superiority in number of leaves/plant of cucumber based on rate of poultry manure received in tons/hectare was $20>15>10>5>0$.

Higher number of leaves/plant was produced by cucumber stands that received 20 tha $^{-1}$ of

Table 2: Effects of poultry manure on vine length $(\mathrm{cm})$ of cucumber in 2011 and 2012

\begin{tabular}{|c|c|c|c|c|c|c|c|c|c|}
\hline \multicolumn{10}{|c|}{ Weeks after sowing } \\
\hline & 4 & & & 6 & & & 8 & & \\
\hline & \multicolumn{9}{|c|}{ Vine length $(\mathrm{cm})$} \\
\hline & 2011 & 2012 & Mean & 2011 & 20012 & Mean & 2011 & 20012 & Mean \\
\hline \multicolumn{10}{|c|}{$\begin{array}{l}\text { Rates of poultry manure } \\
\text { tons /ha }\end{array}$} \\
\hline 0 & $45.0_{\mathrm{e}}$ & $47.2 \mathrm{e}$ & $46.1_{\mathrm{e}}$ & $78.4_{\mathrm{e}}$ & $82.6_{\mathrm{e}}$ & $80.5_{\mathrm{e}}$ & $92.0_{\mathrm{e}}$ & $96.4_{\mathrm{e}}$ & $94.2 \mathrm{e}$ \\
\hline 5 & $62.4_{\mathrm{d}}$ & $68.6_{d}$ & $65.5_{\mathrm{d}}$ & $92.2_{\mathrm{d}}$ & $96.4_{d}$ & $94.3_{\mathrm{d}}$ & $108.4_{\mathrm{d}}$ & $112.4_{\mathrm{d}}$ & $110.4_{d}$ \\
\hline 10 & $80.0_{c}$ & $82.2_{\mathrm{c}}$ & $81.1_{\mathrm{c}}$ & $118.4_{c}$ & $122.2_{\mathrm{c}}$ & $120.3_{c}$ & $138.2_{\mathrm{c}}$ & $144.0_{\mathrm{c}}$ & $141.1_{\mathrm{c}}$ \\
\hline 15 & $92.2_{b}$ & $96.2_{b}$ & $94.2_{b}$ & $126.2_{b}$ & $130.2_{\mathrm{b}}$ & $128.2_{\mathrm{b}}$ & $146.4_{b}$ & $148.4_{b}$ & $147.4_{b}$ \\
\hline 20 & $112.0_{\mathrm{a}}$ & $120.4_{\mathrm{a}}$ & $116.2_{\mathrm{a}}$ & $140.4_{a}$ & $148.6_{\mathrm{a}}$ & $144.5_{\mathrm{a}}$ & $162.2_{\mathrm{a}}$ & $172.4_{\mathrm{a}}$ & $167.3_{\mathrm{a}}$ \\
\hline
\end{tabular}

Means with the same letter(s) under the same column are not significantly different $(\mathrm{P} \leq 0.05)$ using Duncan Multiple Range test (DMRT)

\section{Effects of poultry on number of leaves/ plant of cucumber in 2011 and 2012}

The response of number of leaves/plant of cucumber to poultry manure in 2011 and 2012 is shown in Table 3 . There were gradual increases in number of leaves/plant from 4-8 weeks after planting. Plants that received 20 poultry manure possibly because the manure established and maintained soil physical condition for plant growth. This is consistent with the reports of Lombin et al., (1992), Mangila et al., (2007), and Enujeke et al., (2013) which indicated that poultry manure (the richest known animal manure) is essential for establishing and maintaining the optimum soil 
physical condition for plant growth. It is also synonymous to the findings of Agbede et al., (2008), and Ewulo et al., (2008) who reported that poultry manure is not only cheap and effective source of $\mathrm{N}$ for sustainable crop production, but improves soil physical properties by reducing temperature, bulk, density, and increasing total porosity, if higher rates are applied. ter holding capacity, and increased moisture availability which favoured the release of more nutrients for higher growth and yield. This is in consonance with the findings of John et al., 2004 who attributed the vigorous growth and increased fruit yield of watermelon to higher supply of nutrient elements from the applied manure.

Table 3: Effects of poultry manure on number of leaves/plants of watermelon in 2011 and 2012

\begin{tabular}{|c|c|c|c|c|c|c|c|c|c|}
\hline \multicolumn{10}{|c|}{ Weeks after sowing } \\
\hline & 4 & & & 6 & & 8 & & & \\
\hline & \multicolumn{9}{|c|}{ Number of leaves/plants } \\
\hline & 2011 & 2012 & Mean & 2011 & 2002 & Mean & 2011 & 2012 & $\overline{\text { Mean }}$ \\
\hline \multicolumn{10}{|c|}{$\begin{array}{l}\text { Rates of poultry } \\
\text { manure tons /ha }\end{array}$} \\
\hline 0 & $6.0_{\mathrm{e}}$ & $6.6_{\mathrm{e}}$ & $6.3_{\mathrm{e}}$ & $28.0_{\mathrm{e}}$ & $32.2 \mathrm{e}$ & $30.1_{\mathrm{e}}$ & $42.4_{\mathrm{e}}$ & $44.2 \mathrm{e}$ & $43.3_{\mathrm{e}}$ \\
\hline 5 & $7.8_{d}$ & $8.2_{\mathrm{d}}$ & $8.0_{\mathrm{d}}$ & $32.4_{d}$ & $36.0_{d}$ & $34.2_{\mathrm{d}}$ & $44.6_{d}$ & $46.6_{d}$ & $45.6_{d}$ \\
\hline 10 & $9.6_{\mathrm{c}}$ & $9.8_{\mathrm{c}}$ & $9.7 \mathrm{c}$ & $36.4_{c}$ & $38.6_{c}$ & $37.5_{c}$ & $48.0_{\mathrm{c}}$ & $50.2_{\mathrm{c}}$ & $49.1_{c}$ \\
\hline 15 & $12.0_{\mathrm{b}}$ & $12.2_{\mathrm{b}}$ & $12.1_{b}$ & $38.6_{b}$ & $42.6_{b}$ & $40.6_{b}$ & $52.4_{b}$ & $54.6_{\mathrm{b}}$ & $53.5_{\mathrm{b}}$ \\
\hline 20 & $14.4_{\mathrm{a}}$ & $14.8_{\mathrm{a}}$ & $14.6_{\mathrm{a}}$ & $44.4_{\mathrm{a}}$ & $48.2_{\mathrm{a}}$ & $46.3_{\mathrm{a}}$ & $54.6_{\mathrm{a}}$ & $58.2 \mathrm{a}$ & $56.4_{\mathrm{a}}$ \\
\hline
\end{tabular}

Means with the same letter (s) under the same column are not significantly different $(\mathrm{P} \leq 0.05)$ using Duncan Multiple Range test (DMRT)

\section{Effects of poultry manure on fruit diame- ter $(\mathrm{cm})$ of cucumber in 2011 and 2012}

The response of fruit diameter of cucumber to poultry manure in 2011 and 2012 is shown in Table 4. Plants that received 20 tha $^{-1}$ of manure had highest fruit diameter of $16.6 \mathrm{~cm}$ in 2011, while plants in the control plot had the lowest fruit diameter $(12.0 \mathrm{~cm})$. In 2012, plants that received 20 tha $^{-1}$ of manure were also superior in fruit diameter with value of $16.8 \mathrm{~cm}$, while plants in the control plot had the lowest fruit diameter with value of 12.6 $\mathrm{cm}$. The superiority in fruit diameter ofCucumber based on the rate of application of poultry manure in tons/hectare was $20>15>10>5>0$.

The fruit diameter of plants that received 20 tha $^{-1}$ of poultry manure was higher than the fruit diameter of plants that received other rates of manure possibly because the high rate of manure reduced soil erosion, increased wa-
Table 4: Effects of poultry manure on fruit diameter (cm) of cucumber in 2011 and 2012

\begin{tabular}{|c|c|c|c|}
\hline & \multicolumn{3}{|c|}{ Fruit diameter $(\mathrm{cm})$} \\
\hline & 2011 & 2012 & Mean \\
\hline \multicolumn{4}{|c|}{$\begin{array}{l}\text { Rates of poultry manure } \\
\text { tons / ha }\end{array}$} \\
\hline 0 & $12.0_{\mathrm{c}}$ & $12.6_{\mathrm{c}}$ & $12.3_{\mathrm{c}}$ \\
\hline 5 & $13.8_{b}$ & $14.4_{b}$ & $14.1_{b}$ \\
\hline 10 & $14.2_{\mathrm{b}}$ & $14.6_{b}$ & $14.4_{b}$ \\
\hline 15 & $14.8_{\mathrm{b}}$ & $15.2_{\mathrm{b}}$ & $15.0_{\mathrm{b}}$ \\
\hline 20 & $16.6_{\mathrm{a}}$ & $16.8_{\mathrm{a}}$ & $16.7_{\mathrm{a}}$ \\
\hline
\end{tabular}

Means with the same letter(s) under the same column are not significantly different $(\mathrm{P} \leq 0.05)$ using Duncan Multiple Range test (DMRT)

Effects of poultry manure on fruit length (cm) of cucumber in 2011 and 2012

The response of fruit length of cucumber to poultry manure in 2011 and 2012 is shown in Table 5. Plants that received 20 tha $^{-1}$ of manure had highest fruit length of $22.4 \mathrm{~cm}$ in 
2011, while plants in the control plot had the lowest fruit length $(16.0 \mathrm{~cm})$. In 2012, plants that received 20 tha $^{-1}$ of manure were also superior in fruit length with value of $22.8 \mathrm{~cm}$, while plants in the control plot had the lowest fruit length with value of $16.2 \mathrm{~cm}$. The superiority in fruit length of cucumber based on the rate of application of poultry manure in tons/ hectare was $20>15>10>5>0$.

Poultry manure application rate of $20 \mathrm{t} / \mathrm{ha}^{-1}$ resulted in higher fruit length of cucumber possibly because that rate was compatible with the crop's requirement for yield enhancement in Asaba Agro-ecological Zone. This is in harmony with the report of Enujeke (2013) who attributed the higher yield of improved maize obtained from the application of high rate of poultry manure to possible compatibility with the crop's requirement in the agroecological zone. It is also consistent with the report of DIPA (2006) who suggested that manure should be applied at rates and times of the year that are compatible with the nutrient requirement and growing characteristics of the crop so as to achieve the desired growth and yield enhancement.

Table 5: Effects of poultry manure on fruit length (cm) of Cucumber in 2011 and 2012

\begin{tabular}{|l|l|l|l|}
\hline \multicolumn{4}{|l|}{ Fruit length (cm) } \\
\hline & $2011^{-}$ & $2012^{-}$ & Mean \\
\hline $\begin{array}{l}\text { Rates of poultry } \\
\text { manure tons /ha }\end{array}$ & & & \\
\hline 0 & $16.0_{\mathrm{d}}$ & $16.2_{\mathrm{d}}$ & $16_{\mathrm{d}}$ \\
\hline 5 & $17.7_{\mathrm{c}}$ & $17.9_{\mathrm{c}}$ & $17.8_{\mathrm{c}}$ \\
\hline 10 & $18.4_{\mathrm{c}}$ & $18.6_{\mathrm{c}}$ & $18.5_{\mathrm{c}}$ \\
\hline 15 & $20.2_{\mathrm{b}}$ & $20.4_{\mathrm{b}}$ & $20.3_{\mathrm{b}}$ \\
\hline 20 & $22.4_{\mathrm{a}}$ & $22.8_{\mathrm{a}}$ & $22.6_{\mathrm{a}}$ \\
\hline
\end{tabular}

Means with the same letter (s) under the same column are not significantly different $(\mathrm{P} \leq 0.05)$ using Duncan Multiple Range test (DMRT)

\section{Effects of poultry manure on weight of fruit $\left(\right.$ tha $\left.^{-1}\right)$ of cucumber in 2011 and 2012}

The response of weight of fruit of cucumber to poultry manure in 2011 and 2012 is shown in Table 6. Plants that received 20 tha $^{-1}$ of manure had highest weight of fruit $\left(48.1\right.$ tha $\left.^{-1}\right)$ in 2011, while plants in the control plot had the lowest fruit weight $\left(14.2\right.$ tha $\left.^{-1}\right)$. In 2012, plants that received 20 tha $^{-1}$ of manure were also superior in fruit weight with value of 50.5 tha $^{-1}$, while plants in the control plot had the lowest fruit weight with value of 16.4 tha 1 . The superiority in fruit weight of cucumber based on the rate of application of poultry manure in tons/hectare was $20>15>10>5>0$.

Higher fruit weight was obtained from cucumber plants that received 20 tha $^{-1}$ of poultry manure possibly because higher rates of manure improved the soil conditions for crop establishment as well as released adequate nutrient elements for yield enhancement. This is in harmony with the reports Aliyu (2000), Adekiya and Ojeniyi (2002), Mangila et al., (2008), and Agbede et al., (2008) which indicated that higher rates of manure increases crop yield.

Table 6: Effects of poultry manure on weight of fruits of Cucumber in 2011 and 2012

\begin{tabular}{|l|l|l|l|}
\hline & \multicolumn{3}{|l|}{ Weight of fruits $\left(\right.$ tha $\left.^{-1}\right)$} \\
\hline & $2011^{2}$ & $2012^{2}$ & Mean \\
\hline $\begin{array}{l}\text { Rates of poultry } \\
\text { manure tons /ha }\end{array}$ & & & \\
\hline 0 & $14.2_{\mathrm{e}}$ & $16.4_{\mathrm{e}}$ & $15.3_{\mathrm{e}}$ \\
\hline 5 & $19.4_{\mathrm{d}}$ & $23.2_{\mathrm{d}}$ & $21.3_{\mathrm{d}}$ \\
\hline 10 & $26.5_{\mathrm{c}}$ & $28.3_{\mathrm{c}}$ & $27.4_{\mathrm{c}}$ \\
\hline 15 & $35.3_{\mathrm{b}}$ & $39.5_{\mathrm{b}}$ & $37.4_{\mathrm{b}}$ \\
\hline 20 & $48.1_{\mathrm{a}}$ & $50.5_{\mathrm{a}}$ & $49.3_{\mathrm{a}}$ \\
\hline
\end{tabular}

Means with the same letter(s) under the same column are not significantly different $(\mathrm{P} \leq 0.05)$ using Duncan Multiple Range test (DMRT)

\section{CONCLUSION AND RECOMMENDA- TIONS}

This study was carried out to evaluate the growth and yield responses of cucumber to five different rates of poultry manure in 
Asaba area of Delta State, Nigeria. The result of the study showed that plants that received 20 tha $^{-1}$ of poultry manure were superior in the parameters tested. Therefore, based on the findings of the study, it canbe recommended that farmers apply 20 tha $^{-1}$ of poultry manure to increase growth and yield of cucumber in the study area. Further research work is, however, necessary in this area so as to prevent farmers from applying very high rates which may become detrimental to soil or crop.

\section{REFERENCES}

Adekiya, A.O. and Ojeniyi, S.O. 2002.Evaluation of tomato growth and soil properties under methods of seedling bed preparation in an Alfisol in the rainforest zone of southwest Nigeria. Bioresource Technol. 96: 509-516.

Adetula O, Denton L 2003 Performance of vegetative and yield accessions of cucumber (Cucumis sativa L.) Horticultural Society of Nigeria (HORTSON) Proceedings of 21 st annual conference 10-13 Nov, 2003

Agbede, T.M., Ojeniyi, S.O. and Adeyemo, A.J. 2008.Effect of Poultry Manure on Soil physical and chemical properties, growth and grain yield of sorghum in Southwest, Nigeria, Am.-Eurasian J. Sustain. Agric. 2(1): 72-77.

Aliyu, L. 2000. The effects of organic and mineral fertilizer on growth, yield and composition of pepper (Capsicum annum L). Biol. Agric. Hort. 18: 29-36.

Bremmer, J. M. and C. S. Mulvaney 1982: Total nitrogen In: Page A. L. Miller, R. H. and Keeney, D. R. (ed.) Methods of soil analysis. Part 2.Agron 9, Madison. W.I. p. 149-157.

Dauda, S.N., Ajayi, F.A. and Ndor E. 2008. Growth and Yield of Watermelon (Citrulluslanatus) as Affected by Poultry Manure Application. Journal of Agriculture \& Social Sciences.; 121-124. http:// www.fspublishers.org (accessed 2009 November 10).

DIPA 2006. Handbook of Agriculture: facts and figures for farmers, students and all interested in farming. Directorate of Information and Publications of Agriculture. Indian Council of Agricultural Research, New Delhi, p. 435.

Duke J 1997.The green pharmacy. St Martins Press, New York.

Egbuchua, C. N. 2007 Pedological characterization and fertility evaluation of some wetlands soils in Delta State. Ph.D Thesis (unpublished). Delta State University, Abraka, Nigeria.

Eifediyi, E. K. and Remison, S. U. 2010. Growth and yield of cucumber (Cucumis sativum L.) as influenced by farm yard manure and inorganic fertilizer. Journal of Plant Breeding and Crop Science 2(7): 216-220.

Enujeke E.C., Ojeifo I.M, and Nnaji G.U 2013 Residual effects of organic manure and inorganic fertilizer on maize grain weight and some soil properties in Asaba area of Delta State. International Journal of Advanced Biological Research 3(3):433-442. Society for Science and Nature, India.

Enujeke, E.C. 2013. Effects Of Poultry Manure On Growth And Yield Of Improved Maize In Asaba Area of Delta State, Nigeria. IOSR Journal of Agriculture and Veterinary Science (IOSR-JAVS).4, (5): 2430. International Organization of Scientific Research, India.

Ewulo, B. S. Ojeniyi, S. O. and Akanni, D. A. 2008.Effect of poultry manure on selected soil physical and chemical properties, growth, yield and nutrient status of tomato. African Journal of Agricultural Research Vol. 3 (9), pp. 612-616,. http:// www.academicjournals.org/AJAR (accessed 2009 November 10).

FMANR-Federal Ministry of Agricultural and Natural Resources 1996 Soil fertility investigation (In 5 volumes); Fertility ratings.Produced by the Federal Ministry of Agriculture, Lagos, Nigeria.

Gee, G. W and J. W. Bauder 1986 Particle size analysis p. 404-407. In A Klute (ed) Methods of soil analysis. Part 1 ( $2^{\text {nd }}$ ed. Agron. 
Monogr. 9. ASA and SSSA. Madison W.I. USA.

IITA-International Institute for Tropical Agriculture 1979 Laboratory manual for soil and plant analysis. Manual series 7, IITA, Ibadan, Nigeria.

Jarret, B., R. Bill, W. Tom and A. Garry, 1996.Cucurbits Germplasm Report, pp: 29-66. Watermelon National Germplasm System, Agricultural Service, U.S.D.A.

John, L.W., Jamer, D.B. Samuel, L.T. and Warner, L.W. 2004. Soil Fertility and Fertilizers: An Introduction to Nutrient Management, Pearson Education, Indiapp: 10653.

Lombin, L.G; Adeputu, J.A and Ayetade, K.A 1991.Complementary use of organic manures and inorganic fertilizers in arable crop production. Proceeding of National organic fertilizer seminar held in October $20^{\text {th }}-22^{\text {nd }}$ at University of Ibadan, Ibadan.Pp 146 -162.

Mangila, E., Tabiliran, F.P., Naguit., M.R.A and Malate, R 2007. Effects of Organic Fertilizer on the Yield of Watermelon. Threshold 2. January-December, 2007, pp 27-35.

Nelson, D. W and I. E. Sommers 1982 Organic Carbon. In Page A.L. Miller, R. H. and Keeney, D. R. (ed) Methods of Soil analysis. Part 2 Agron, Monogr. 9 ASA and SSSA, Madison, W.I. USA.

NIMET-Nigerian Meteorological Agency 2011 Climate information Bulletin 2011-2012 Asaba, Delta State, Nigeria.

Okonmah, L.U. 2011. Effects of different types of staking and their cost effectiveness on the growth, yield and yield components of cucumber (Cumumis sativa L). international Journal of Agri Science Vol. 1 (5): 290-295. International Academic Journals, Germany.

Roades, J. D. 1982 Cation Exchange Capacity. In Page, A. L. Miller, R. H. and Keeney, D.R. (eds) Methods of soil analysis. Part 2 Agron. Monogr. ASA, SSSA, Madison, W.I. USA.

Vimala P, Ting CC, Salbiah H, Ibrahim B, Ismail L 1999 Biomass production and nutrient yields of four green manures and their effects on the yield of cucumber. Journal of Tropical Agric and Food Science 27:47
-55 .

Wahua, T.A.T 1999. Applied statistics for scientific studies. Afrika-Link Books, Nigeria, pp. $250-287$. 